\title{
The Implementation of Asset Handover Based on Law Number 25 of 2008 Concerning the Establishment of Sungai Penuh City
}

\author{
$1^{\text {st }}$ JeferOktriYesya \\ Faculty of Social Sciences, \\ UniversitasNegeri Padang, \\ Padang, Indonesia \\ jeferoktri@gmail.com \\ $2^{\text {nd }} \mathbf{H}$. AfrivaKhaidir* \\ Faculty of Social Sciences, \\ UniversitasNegeri Padang, \\ Padang, Indonesia \\ af.khaidir@fis.unp.ac.id
}

\author{
$3^{\text {rd }}$ DasmanLanin \\ Faculty of Social Sciences, \\ UniversitasNegeri Padang, \\ Padang, Indonesia
}

\begin{abstract}
The autonomy granted to the district area and city is carried out by giving broad, real, and responsible authority proportionally to the government. Most of the governmental authority is givento the regions. There by, the region has the right to ask to make regional expansion in order to be able to manage all its potential and wealth, so that development in the regions can be more advanced. Data information is required to determine the factors that cause the slow implementation of assethandover from the Government of Kerinci District to the Government of Sungai Penuh City. The purposeof determining the factors that cause the slow implementation of asset handover is to obtain a solution that can be done by local governments to accelerate the process of asset handover. The research locations are the
\end{abstract}

\section{INTRODUCTION}

Indonesia is a country that applies a democratic system, which is a governmental system of the people by the people for the people to achieve a shared goal. The Constitution of the Republic of Indonesia of 1945 then granted the region the freedom to hold Regional Autonomy. The definition of Regional Autonomy is stated in Law Number
Kerinci District and Sungai Penuh City. The method used in this study is a qualitative descriptive approach. Based on the research results, it is know that there are several factors causing the slow implementation of asset handover from Kerinci District to Sungai Penuh City, in which there are no new buildings to be occupied by the Government of Kerinci District. Consequently, it takes a long time to prepare a new building to be occupied. Then, there is a different interpretation from the Government of Kerinci District and the Government of Sungai Penuh City on the Law Number 25 of 2008 concerning the Establishment of Sungai Penuh City.

Keywords-Implementation,Handover, Asset, Sungai Penuh City

32 of 2004 concerning Local Government as amended by Law Number 23 of 2014. Regional Autonomy is defined as the rights, authorities, and obligations of autonomous regions to regulate and manage their own government affairs and interests of local community in the system of the Republic of Indonesia. This Regional Autonomy is carried out with the hope that it can accelerate the realization of 
community's welfare through improved services, empowerment, and community participation, as well as increasing regional competitiveness by regarding the principles of democracy, equity, justice, special features and uniqueness of a region in the system of the Republic of Indonesia [1].

Accourding to Bagir Manan, Regional Autonomy is political decentralization, but decentralization is not the same as autonomy. Autonomy is the core of decentralization so that decentralization in this case is decentralization which creates the authority for regions to regulate (legislative) and manage (executive) government affairs themselves [2].

Sungai Penuh City was once the capital of the Kerinci District. Then, in early 2005, the community of Sungai Penuh requested the establishment of a new region so that they could regulate and manage their own government at that time in accordance with what was meant in Article 1 section (5) of Law Number 32 of 2004 concerning Regional Government. The Government of Kerinci District received the aspirations of the community of Sungai Penuh in the form of the issuance of the Decree of the Regent of Kerinci Number 21 of 2005 dated March 10, 2005 concerning the Approval of the Expansion of Kerinci District into KerinciDistrict and the Autonomous City of Sungai Penuh.

Following the issuance of Decree of the Regent of Kerincion the agreement to split Kerinci District with Sungai Penuh, the Regional People's Representative Assembly (RPPA) of Kerinci District issued a Decree the Regional People's Representative Assembly of Kerinci District Number 09 of 2006 dated April 13, 2006 concerning the Approval of the Expansion of Kerinci District into Kerinci District and the Autonomous City of Sungai Penuh.

After the Regent of Kerinci continued the follow-up of the Approval Letter of RPPA of Kerinci District, then at the provincial level, the Regional People's Representative Assembly of Jambi Province approved the regional expansion by issuing an Approval Letter of the Regional People's Representative Assembly of
Jambi Province Number 9 of 2006 dated July 3, 2006 concerning the Approval of RPPA of Jambi Province of the Expansion of Kerinci District into Kerinci District and the Autonomous City of Sungai Penuh, followed by the approval of Jambi Governor in the proposal letterof Jambi Governor to the Minister of Home Affairs Number 100/3884/Pemotda dated September 1, 2006 concerning the Proposal of Expansion of Kerinci District and the Establishment of Sungai Penuh City in Jambi Province.

After obtaining approval from the RPPA of Jambi Province and the Governor of Jambi, the Regent of Kerinci determined the location of the prospect and the name of the Capital of Kerinci District, with the area coverage through a Decree of the Regent of Kerinci Number 135.7/Kep.31/2007 dated March 10, 2007 concerning the Determination of the Location of Prospect for the Capital of Kerinci District. The Decree of the Regent of Kerinci Number 135.7/Kep.236/2007 dated June 16, 2007 concerning Approval of the City Name, Capital, and Regional Coverage of the Prospective City as Expansion of Kerinci District.The President of the Republic of Indonesia finally approved the establishment of Sungai Penuh City on the basis of Law Number 25 of 2008 concerning the Establishment of Sungai Penuh City which was approved by the President of the Republic of Indonesia by establishing Sungai Penuh City to be an Autonomous City.

This handover of regional assets is regulated in Decree of the Minister of Home Affairs Number 42 of 2001 concerning Guidelines for the Implementation of Goods and Debt Handover in Newly Formed Regions in Article 2 (two) section 1 (one). This is also regulated in Law Number 25/2008 concerning the Establishment of Sungai Penuh City in Jambi Province, Chapter V concerning Personnel, Assets and Documents.

The authors see what is happening now that the location of the main district government, which is Kerinci District is still in the Sungai Penuh area which has been the capital of Kerinci District, in the sense that the center of government of Kerinci District is 
located in the Sungai Penuh City area. Therefore most of the important asset of the Government of Kerinci District is in the Sungai Penuh City area. These assets must be handed over by the Government of Kerinci District to the Government of Sungai Penuh City. However, in fact, the handover of these assets has not been realized until recently as specified in Law Number 25 of 2008 concerning the Establishment of Sungai Penuh City.

In the first stage of asset handover, the Government of Kerinci District only handed over some of the assets to the Government of Sungai Penuh City, so the next stage of asset handover must be made. On March 24, 2016, the second phase of asset handover was carried out. The period of the asset handover from the first stage to the second stage is quite long, even though the period for the asset handover of the Government of Kerinci District to the Government of Sungai Penuh City as mandated by Law Number 25 of 2008 concerning the Establishment of Sungai Sungai City is no later than 5 (five) years.

Head of the DPPKA Office of Sungai Penuh City said that the second stage of asset handover had no problems and would be implemented immediately. However, in the second stage of asset handover, it turned out that the assets had not yet been fully handed over. There were still assets that could not be handed over by Kerinci District due to constraints in the absence of a new office building that could be used by the Government of Kerinci District. In this case, it can be ensured that there will be a third stage of asset handover by the Government of Kerinci District to the Government of Sungai Penuh City for assets that have not yet been handed over.

The Government of Sungai Penuh City will propose the third stage of asset handover so that they can be quickly implemented after the second stage of asset handover. It isbecause productive assets, such as the Regional Water Company (RWC) and Regional General Hospital of Mayjen H.A Thalib Kerinciare urgently needed by the Government of Sungai Penuh City to improve services to the community and increase Local Revenue.

There are assets that have not been submitted until now, so that the process of regional asset handover has taken 11 (eleven) years after the Mayor Official of Sungai Penuh is inaugurated. The Government of Kerinci District is 6 (six) years late from the specified time. The Law Number 25/2008 concerning the Establishment of Sungai Penuh City seems ambiguous for both Governments, so there was a misunderstanding in the interpretation of the Law.

Based on the explanation above, it can be seen that there is a conflict between the two Governments in fighting over the same matter, which is the regional assets within the Government of Sungai Penuh City area, so that there are obstacles to the implementation of Law Number 25/2008 concerning the Establishment of Sungai Penuh City. So far, the Government of Kerinci District and the Government of Sungai Penuh City have only carried out 2 (two) stages of asset handover. There is still no information on when the third stage of asset handover will be done.

\section{METHOD}

This article is the result of a qualitative descriptive research carried out within the government environment of Kerinci District and Sungai Penuh City which is intended to find out the root of the problem of the delay in the Implementation of Asset Handover Based on Law Number 25 of 2008 concerning the Establishment of Sungai Penuh City. To find out the root of the problem, the authors conducted in-depth interviews with relevant officials in several Regional Apparatus Organizations.

This study uses descriptive qualitative methods by applying Implementation theory of Hogwood and Gunn The authors will use the conflict resolution theory as a supporting theory [3].

The selection of respondents is done by purposive sampling with a total of 20 respondents. All data obtained from in-depth interviews are then analyzed using the spradley model. By using this analysis, domain analysis, taxonomic analysis, 
component analysis, and theme analysis will do carried out to process the data [4].

To find out the root of the problem of the slow process of the Asset Handover based on Law Number 25 of 2008 concerning the Establishment of Sungai Penuh City, the data are collected and categorized generally into 3 (three) aspects. First, is there any presence or absence of efforts made by the Government of Kerinci District and the Government of Sungai Penuh City in carrying out the asset handover process in accordance with the mandate of Law Number 25 of 2008 concerning the Establishment of Sungai Penuh City. Second, what are the obstacles of the Government of Kerinci District and the Government of Sungai Penuh City in carrying out the asset handover proccess. Third, how is the direction of the policy on the settlement of the asset handover in Sungai PenuhCity.

\section{RESULTS AND DISCUSSION}

\section{The process of asset handover in several regionsin previous studies}

The relevant previous studies that have been written include; First, a study conducted by Dyah Ayu Vijaya entitled "Settlement of Regional Asset Disputes Due to the Establishment of Metro City as Expansion of Central Lampung District" [5]. The disputes over regional assets between Central Lampung District and Metro City occurred because the agreement or MoU made by both parties was not in accordance with the Ministry of Home Affairs Number 42 of 2001. There were differences of opinion between the Government of Central Lampung District and the Government of Metro City regarding the process of regional asset handover that had to be approved by the RPPA. The dispute resolution had been mediated by the Regional Government of Lampung Province, but until now the dispute over the assets of Central Lampung District and Metro City was still a polemic.

Second, a study by Iin Hidayah Nawi rentitled "Regional Asset Handover of Luwu District to Palopo City Based on Law Number 11 of 2002 concerning the Establishment of Mamasa District and Palopo City in South
Sulawesi Province" [6]. The regional asset handover of LuwuDistrict to Palopo City based on Law Number 11 of 2002 concerning the Establishment of Mamasa District and Palopo City in South Sulawesi Province (Law on the Establishment of Palopo City) had not been implemented optimally.

This is because the position of LuwuDistrict as the main region must shift away from Palopo City which was once its capital. As a result, it is the main region that had to start from the beginning of the construction of supporting infrastructure for government administration because all of the assets were previously in the Palopo City area as a newly formed region. Therefore, a number of regional assets belonging to the Government of Luwu District that are in Palopo City which should have been handed over according to existing regulation scould not yet be fully handed over and remained functioning and under the ownership and control of the Government of Luwu District.

The factors that hampered the process of asset handover from the Government of Luwu District to the Government of Palopo City were weaknesses in terms of the incomplete Law on the Establishment of Palopo City, different interpretations of the Law of Establishment of Palopo City, the required factors from the Government of Luwu District as a shifting area and there has been no official request from the Government of Palopo City to hand over these assets. In addition, other factors are the lack of intensive communication and firmness between the two regions and the selfishness of the two regions.

Third, a study by Muhamad Rizky entitled "Asset Conflict in the Area of Expansion (A Study of Conflict of Traditional Market Asset Handover in South Tangerang)" [7]. This study discusses the conflict of assets in the area of expansion which is the constrained handover of regional assets, especially traditional market assets in South Tangerang City. The researcher found that after the expansion of the South Tangerang City area, there were obstacles in the regional asset handover, especially regionally-owned enterprises, one of which was the traditional 
market. From the study conducted based on field studies in the form of interviews and observations, the researcher found that the inhibiting factors in the asset handover consisted of several factors including structural factors, importance factors, human relations factors, and data factors.

The Process of Asset Handover Based on Law Number 25 of 2008 Concerning the Establishment of Sungai Penuh City

The process of asset handover based on Law Number 25 of 2008 concerning the Establishment of Sungai Penuh City is as follows:

1) The Kerinci Regent together with the Mayor Official of Sungai Penuh inventory, regulate, and carry out the transfer of personnelas well as asset and document handover to the Government of Sungai Penuh City;

2) The transfer of personnel as referred to above is carried out no later than 6 (six) months from the inauguration of the mayor official;

3) The asset and document handover as referred to above is done no later than 5 (five) years from the inauguration of the mayor official;

4) Personnel referred to include civil servants who because of their duties and abilities are required by Sungai Penuh City;

5) The transfer of personnel and the asset and document handover to Sungai Penuh City are facilitated and coordinated by the Governor of Jambi;

6) The salaries and allowances of civil servants as referred to, as long asthey have not been determined by the Regional Revenue and Expenditure Budget of Sungai Penuh Cityare charged to the revenue and expenditure budget from the origin of the work unit of the relevant personnel in accordance with statutory regulations;

7) The assets and documents as referred to include;

a. Movable and immovable properties that are belong/controlled and/or utilized by the Government of Sungai Penuh City within the Sungai Penuh
City area;

b. Regional Owned Enterprises (BUMD) of Kerinci District whose position, activities, and location are in Sungai Penuh City;

c. Debts of Kerinci District whose use is for Sungai Penuh City; and

d. Documents and archives which by their nature are needed by Sungai Penuh City.

8) If the handover and transfer of assets and documents as referred to are not carried out by the Regent of Kerinci, the Governor of Jambi as a representative of the Government must complete it.

9) The transfer of personnel and the asset and document handover as referred to are reported by the Governor of Jambi to the Minister of Home Affairs [8].

If we look at article 13 section (3), the Law states that "The asset and document handover as referred to in section (1) is made no later than 5 (five) years since the inauguration of the mayorofficial". It is clear that the asset and document handover is no later than 5 (five) years since the inauguration of the mayor official. However, it has exceeded 5 (five) years of inauguration of the mayor official, but the asset handover from Kerinci District to Sungai Penuh City is not yet fully carried out. This certainly violates the administrative procedures and regulations already determined.

Based on the results of interviews and document searches conducted, 2 (two) conditions were identified that were related to the slow process of asset handover from the Government of Kerinci District to the Government of Sungai Penuh City. First, according to the explanation of the Government of Kerinci District about the obstacles that cause delayed and late asset handover to Sungai Penuh City, one of them is due to the absence of new buildings to be occupied by the Government of Kerinci District. It takes a long time to prepare a new building to be occupied.

Therefore, the asset handover between Kerinci District and Sungai Penuh City has not yet been carried out until now as it should. As 
explained in the introduction, there are obstacles that were conveyed by the Kerinci District partyas the Main District in the process of asset handover from the Kerinci District to Sungai Penuh City. In this regard, the law regulates all procedures for the asset handover referred to, but the problem is the internal factor of the Government of Kerinci District, which by Administrative Law, does not in any way affect the passage of the law.

Second, there is a different interpretation of Law Number 25 of 2008 concerning the Establishment of Sungai Penuh City, which is in Article 13 section (7) letter a. stating that "Movable and immovable properties that are belong/controlled and/or utilized by the Government of Sungai Penuh City within the Sungai Penuh City area," in this case the Government of Kerinci District interprets the article that not all Kerinci District assets must be handed over to Sungai Penuh City, but only assets that have been controlled by the Government of Sungai Penuh City that must be handed over.

It is different to the interpretation of the Government of Sungai Penuh City, according to Deputy Mayor of Sungai Penuh, $\mathrm{H}$. Zulhelmi, S.H., M.M., in an interview on January 6, 2017, that Article 13 section (7) letter a has been explained in detail, which in essence stipulates that all assets of the Government of Kerinci District in the Sungai Penuh City must be handed over.

This explanation was supported by GenimanSatria, S.H., M.H. as the legal practitioner in an interview session on Monday, July 9, 2018, that said, "The article clearly states that the Regent of Kerinci along with the Mayor Official of Sungai Penuh inventory, regulate, and carry out the transfer of personnel, as well as asset and document handover to the Government of Sungai Penuh City.

Thus, the assets and documents referred to in this case are movable and immovable properties that are belong/controlled and/or utilized by the Government of Sungai Penuh City within the Sungai Penuh City area, meaning that it is movable or immovable property under the authority of the
Government Sungai Penuh City, which is obviously within the Sungai Penuh City areamust be handed over to the Government of Sungai Penuh City, that is the order. And the guideline actually already exists, that in the Decree of the Minister of Home Affairs Number 42 of 2001 concerning the Guidelines for the Goods and Debts handover to Newly Formed Regions in Article 2 (two) section 1 (one) specifying that "Goods controlled and or utilized by the Provincial Government or the District/City Government whose location is within the newly formed region must be handed over and become the property of the newly formed region."

\section{Policy on Settlement of Asset Handover Dispute from Kerinci District to Sungai Penuh City}

According to the final results after calculating the long process of asset handover from Kerinci District to Sungai Penuh City, the way taken was by Audience and Consultation held on December 26, 2016, at Inna Muara Padang Hotel, West Sumatera. The event was attended by M. Shadiq Pasadigoe, $H$. Zulhelmi, Assistant of Government \& Public Welfare, Head of Governance and Head of Subdivision of Regional Autonomy \& Staff. It produced directives as follows:

a. According to the explanation of M. Shadiq Pasadigoe, on October 13, 2016, a meeting was held at the Ministry of Home Affairs regarding asset issues between Kerinci District and Sungai Penuh City. At the meeting, it was concluded that the Ministry of Home Affairs would form a team and go directly to the field. However, it has not been implemented until now;

b. According to the explanation of the Deputy Mayor of Sungai Penuh and Assistant Government and Public Welfare, and Inspector III M. Sadiq Pasadigoe, this is a consequence of expansion and this problem must be resolved immediately because it will have a negative impact, one of which is the lack of service to the community and the obstructed development;

c. Inspector III M. Shadiq Pasadigoe would coordinate with the Secretary General 
regarding the Letter of the Governor of Jambi and the Regent of Kerinci that has not been responded;

d. M. Shadiq Pasadigoe welcomed the hope of the Government of Sungai Penuh City that the Ministry of Home Affairs sent a confirmation letter to the Government of Kerinci District to immediately hand over the assets to the Government of Sungai Penuh City;

e. Assistant of Government and Public Welfare, and Head of Governance of Regional Secretary of Sungai Penuh Cityshould continue to monitor the progress of this problem and report it to the Mayor of Sungai Penuh.

In addition, the community of Sungai Penuh also reported the problem to the Ombudsman of the Republic of Indonesia related to the dispute that occurred. This is justified by the existence of a letter from the Mayor of Sungai Penuh as a follow-up to the summons by the Indonesian Ombudsman to the Mayor of Sungai Penuh with Letter Number 130/35/Setda. Tapem/II/2017. However, at that time, there were quite interesting developments after a clarification meeting by the Indonesian Ombudsman on Tuesday 24/1 at the Indonesian Ombudsman office. The event was attended by Deputy Mayor of Sungai Penuh Zulhelmi, Secretary of Kerinci Afrizal, Head of the Regional Autonomy of Jambi Province Drs. Atma Jaya, Head of Regional Arrangement of the Directorate General of Regional Autonomy of the Ministry of Home Affairs Maurits Valentino, Financial and Development Supervisory Agency (FDSA) Jambi Representative Abdul Chair, AK, CFE, and acknowledged by Republic of Indonesian Ombudsman Member Ahmad Alamsyah Saragih and Head of Ombudsman Representative of Jambi Province M. Taufik Yasak.

In the meeting, 7 (seven) points were agreed, including First, the Kerinci District agreed to hand over assets that had not been submitted to Sungai Penuh City in accordance with the applicable Regulations and Laws. Second, Chief of the High Prosecutors Office of Jambi reviewed the planning of the Kerinci
District office planning involving the Government of Jambi Province, FDSA Jambi, the Government of Kerinci District.Third, the Government of Jambi Provincewould encourage the process of asserting the boundaries of the two regions. Fourth, the Minister of Home Affairs through the Director General of Regional Autonomy would discuss the letter of Jambi Governor regarding the explanation of article 13 section 7 letter a of Law Number 25 of 2008 concerning the Establishment of Sungai Penuh City. Fifth, the Indonesian Ombudsman and the Ministry of Home Affairs would visit the location related to the legal status of the Government building of Kerinci District. Sixth, the Indonesian Ombudsman and the Ministry of Home Affairs would visit the location of the assets of Kerinci Districtin Sungai Penuh that had not been handed over. And seventh, if there is no progress in the asset handover, the Indonesian Ombudsman would issue recommendations.

In fact, there is still no clear result from the dispute resolution process up to now. This certainly makes the community confused onhow this dispute will be resolved to get clarity on the administration of their regional assets.

\section{CONCLUSIONS}

Regarding the main problems above, the solution and policy direction in accelerating the Implementation of Asset Handover Based on Law Number 25 of 2008 concerning the Establishment of Sungai Penuh City, the authors see that there are two alternative of dispute settlement patterns for asset handover, which are as follows; First, the settlement of regional asset disputes through non-legal methods is carried out through Negotiations and Mediation. The settlement of regional asset disputes through this method is administrative in nature within the government. If there is an asset dispute between autonomous regions within a province, the settlement is facilitated by the Governor. However, in practice, the Governor does not have the authority to determine the status of the disputed assets because the authority is in the hands of the central government through the Ministry of Home 
Affairs and the Governor's position is only as a facilitator to resolve the disputes that occur between the autonomous regions.

Second, is the legal settlement of regional asset disputes, conducted by the Supreme Court, the Constitutional Court and the State Administrative Court. Based on data from the Ministry of Home Affairs, it is known that there are 729 regional asset segments have not been finished. Procedurally, the issue of asset segment and disputes that occur between cities/districts must be handled by the provincial government and if the problem of assets is occurred between provinces, it must be resolved by the central government. Even if thereis no certainty, it can be resolved in a justice institution so that the decision of the justice institution can provide legal certainty.

\section{ACKNOWLEDGMENTS}

We want to express special gratitude to all Social Science Education Study Program of Social Science Education Faculty of Universitas Negeri Padang stakeholders who facilitated the process of research and writing this article.

\section{REFERENCES}

[1] Law Number 23 of 2014 concerning Regional Government.

[2] T. Ratnawati. (2010). Satu Dasa Warsa Pemekaran Daerah Era Reformasi: Kegagalan Otonomi Daerah.Jurnal Ilmu
Politik, Edisi 21, pp 218.

[3] Law Number 25 of 2008 concerning The Establisgment of Sungai Penuh City.

[4] S. A. Wahab. (2012).Analisis Kebijakan: Dari Formulasi ke Penyusunan Model-model Implementasi Kebijakan Publik. Jakarta: PT. Bumi Aksara.

[5] Sugiyono. (2016)Metode Penelitian Kuantitatif dan Kualitatif. Bandung: Alfabeta.

[6] D. A. Vijaya. (2015). Settlement of Regional Asset Disputes Due to the Establishment of Metro City as Expansion of Central Lampung District. [Online]. Tersedia: http://digilib unila.ac.id/7239/[Diakses: 28 Oktober 2018

[7] I. H. Nawir. (2014). Regional Asset Handover ofLuwu District to Palopo City Based on Law Number 11 of 2002 Concerning the Establishment of Mamasa District and Palopo City in South Sulawesi Province. [Online]. Tersedia: http://repository. unhas.ac.id/handle/123456789/10961

[Diakses: 28 Oktober 2018]

[8] M. Rizky. (2015). Asset Conflict in the Area of Expansion (A Study of Conflict of Traditional Market Asset Handover in South Tangerang). [Online]. Tersedia: http:// repository.uinjkt.ac.id/depace/handle/123 456789/27404 [Diakses: 29 Oktober 2018] 